Original Research Article

\title{
Cost variation analysis of antipsychotic drugs available in Indian market: an economic perspective
}

\author{
Nishita P. Shah*, Aparna S. Chincholkar, Ranjit J. Wagh, Waseem A. Siddiqui
}

\begin{abstract}
Department of Pharmacology, MIMER Medical College, Talegaon Dabhade, Pune, India
\end{abstract}

Received: 29 December 2016

Received: 01 January 2017

Accepted: 31 January 2017

*Correspondence to:

Dr. Nishita P. Shah,

Email:

drnishitashah90@gmail.com

Copyright: (C) the author(s), publisher and licensee Medip Academy. This is an openaccess article distributed under the terms of the Creative Commons Attribution NonCommercial License, which permits unrestricted noncommercial use, distribution, and reproduction in any medium, provided the original work is properly cited.

\begin{abstract}
Background: Pricing of drugs plays a very important role in a developing country like India especially in the management of chronic conditions. There exists a huge price variation among the different brands of the same drug. Hence this study was planned to find out variation in prices of antipsychotic drugs marketed in India. The objective was to compare the percentage price variation and cost ratio of various formulations of oral and parenteral antipsychotic drugs available in the Indian market.

Methods: Cost of oral and parenteral antipsychotic drugs available in the Indian market manufactured by different companies, in the same strength, number and dosage form was obtained from http://www.medguideindia.com. The percentage price variation and cost ratio of each formulation was calculated.

Results: Among the typical group of antipsychotic drugs, Tab Haloperidol $0.25 \mathrm{mg}$ shows maximum price variation of $650 \%$ and a cost ratio of 7.5 followed by Tab Trifluoperazine $1 \mathrm{mg}$ having a price variation of $555.5 \%$ and a cost ratio of 6.55. Among the atypical group of drugs, tab Risperidone $3 \mathrm{mg}$ shows a price variation of $2282.35 \%$ with a cost ratio of 23.82 followed by Tab Risperidone $4 \mathrm{mg}$ with a price variation of $1976.92 \%$ and a cost ratio of 20.76 .

Conclusions: There is a wide variation between the minimum and maximum cost among the different brands of the same drug in the same formulations. Combined efforts are needed from the regulatory authorities, pharmaceutical companies, physicians and pharmacist towards controlling the prices and attaining maximum economic benefits for the patient.
\end{abstract}

Keywords: Antipsychotic drugs, Branded generics, Cost variation, Pharmacoeconomics

\section{INTRODUCTION}

Pharmaceutical industry has grown at a tremendous pace in India since last few decades. ${ }^{1}$ The Indian market is flooded with enormous number of branded generic drugs both from the domestic and foreign manufacturers. ${ }^{2,3}$ There are more than 1 lakh formulations available for all the category of drugs under various brand names and there is no system of registration of these medicines. ${ }^{3,4}$ This has led to a wide price variation in the cost of different brands of the same formulations. ${ }^{2}$

Pharmacoeconomics plays a very important role in a developing country like India where the cost of drug therapy is one of the major obstacles for effective treatment of a disease ${ }^{5}$.Increasing health care cost causes an economic burden to the patients. ${ }^{5}$ In fact, many studies have indicated that drug prices play a significant role in therapeutic compliance. ${ }^{1}$ To ensure that the essential drugs are available at an affordable price, the Government of India exercises control over the prices through an order called DPCO (Drug Price Control Order). ${ }^{6}$ National Pharmaceutical Pricing Authority (NPPA) implements DPCO. ${ }^{6,7}$ Previously only 74 drugs were under price control in $1995 .{ }^{6,8}$ However under the provision of DPCO 2013, currently 348 drugs are controlled by NPPA. ${ }^{6}$ However only 3 antipsychotic drugs namely Chlorpromazine $(25 \mathrm{mg}, 50 \mathrm{mg}, 100 \mathrm{mg}$ tablets, $25 \mathrm{mg} / 5 \mathrm{ml}$ syrup and $25 \mathrm{mg} / \mathrm{ml}$ injection), Haloperidol $(5 \mathrm{mg} / \mathrm{ml}$ injection) and olanzapine $\left(5 \mathrm{mg}, 10 \mathrm{mg}\right.$ tablets) are under price control. ${ }^{7}$ 
Antipsychotic drugs have been prescribed with an increasing frequency for a variety of psychiatric disorders. ${ }^{9}$ This ranges from acute psychosis, manic and psychotic depressive disorders as well as in chronic conditions like schizophrenia, schizoaffective disorders and delusional disorders. ${ }^{10}$ Most of these are chronic conditions requiring lifelong treatment. ${ }^{11}$ This is responsible for higher medication cost and thus, cost related poor medication adherence is related to adverse health outcomes. ${ }^{12}$

Regarding antipsychotic drugs, with the best of our knowledge hardly any studies are available which compares the cost of different brands available in Indian market. The current study projects a representative view of the existing situation of the cost of various antipsychotic drugs available in Indian market.

Aim of the study was to evaluate the cost of oral and parenteral antipsychotic drugs of different brands currently available in the Indian market.

\section{Objectives}

1. To analyse the difference in cost of different brands for the same dosage of same active drug by calculating percentage variation of cost and cost ratio.

2. To compare the percentage price variation and cost ratio of single drug therapy of oral and parenteral antipsychotic agents across the different brands available in the Indian market.

\section{METHODS}

1. A list of all oral and parenteral antipsychotic drugs available in the Indian market was found out from http://www.medguideindia.com.

2. Cost of same drug in same strength, dosage form manufactured by different companies was found out from the same website.

3. The difference in the maximum and minimum price of the same drug formulation manufactured by different pharmaceutical companies was noted.

4. The percentage variation in price was calculated using the formula:

\section{Price of most expensive brand-Price of least} expensive brand $\times 100$

Price of least expensive brand

5. Drugs were classified into 5 categories depending on the percentage range of price variation. These were as follows:

- $\leq 24.99 \%$

- $25-49.99 \%$

- $50-99.99 \%$

- $100-499.99 \%$

- $\geq 500 \%$
6. Cost ratio, the ratio of the cost of the costliest brand to cheapest brand of the same formulation was calculated. This tells us how many times the costliest brand cost more than the cheapest brand in each formulation

7. The drugs being manufactured by only one company and combinations of antipsychotic drugs were excluded.

\section{Statistical analysis}

Findings of our study were expressed as absolute numbers as well as percentage.

\section{RESULTS}

The prices of a total of 16 antipsychotic drugs available in the Indian market in 72 different formulations were analysed. These formulations are manufactured by different pharmaceutical companies.

Table 1 shows the price variation between typical antipsychotic drugs.

In this group, Tab Haloperidol $0.25 \mathrm{mg}$ shows maximum price variation of $650 \%$ and a cost ratio of 7.5 followed by Tab Trifluoperazine $1 \mathrm{mg}$ having a price variation of $555.5 \%$ and a cost ratio of 6.55 .

Inj.Haloperidol 50mg (1ml) shows minimum price variation of $3.5 \%$ with a cost ratio of 1.03 .

Highest numbers of brands among the typical group are for Tab.Haloperidol $5 \mathrm{mg}$ (40) followed by $\mathrm{Tab}$ Haloperidol 10mg (32).

Table 2 shows the price variation among the atypical group of antipsychotic drugs.

In this group, tab Risperidone $3 \mathrm{mg}$ shows a price variation of $2282.35 \%$ with a cost ratio of 23.82 , indicating that the costliest brand is about 23 times more expensive than the cheapest available brand. Next highest is Tab Risperidone $4 \mathrm{mg}$ with a price variation of $1976.92 \%$ and a cost ratio of 20. 76 .Price variations is maximum in Risperidone group.

Tab Loxapine shows the lowest price variation of $2.63 \%$ and a cost ratio of 1.02 .

Highest number of brands was seen for Tab Olanzapine $5 \mathrm{mg}(94)$.

\section{DISCUSSION}

This study was carried out with the main objective of computing the cost and percentage price variation among the different antipsychotic drugs across the different brands available in the Indian market. 
Table 1: Price variation among typical antipsychotic drugs.

\begin{tabular}{|c|c|c|c|c|c|c|c|}
\hline Drug & Formulation & Dose & $\begin{array}{l}\text { Manufacturing } \\
\text { company }\end{array}$ & $\begin{array}{l}\text { Min price } \\
\text { (INR) }\end{array}$ & $\begin{array}{l}\text { Max price } \\
\text { (INR) }\end{array}$ & $\begin{array}{l}\text { Cost } \\
\text { ratio }\end{array}$ & $\begin{array}{l}\% \text { Price } \\
\text { variation }\end{array}$ \\
\hline \multirow{7}{*}{ Chlorpromazine } & \multirow{7}{*}{7} & $10 \mathrm{mg}$ & 2 & 0.23 & 0.4 & 1.73 & 73.91 \\
\hline & & $25 \mathrm{mg}$ & 12 & 0.18 & 0.72 & 4 & 288.88 \\
\hline & & $50 \mathrm{mg}$ & 16 & 0.28 & 0.9 & 3.21 & 221.42 \\
\hline & & $100 \mathrm{mg}$ & 18 & 0.51 & 1.2 & 2.35 & 135.29 \\
\hline & & $200 \mathrm{mg}$ & 9 & 0.9 & 1.95 & 2.16 & 116.66 \\
\hline & & Inj. $25 \mathrm{mg} / \mathrm{ml}$ & 2 & 4.22 & 8.5 & 2.01 & 101.42 \\
\hline & & Inj. $50 \mathrm{mg} / 2 \mathrm{ml}$ & 6 & 1.06 & 2.5 & 2.35 & 135.84 \\
\hline \multirow{11}{*}{ Haloperidol } & \multirow{11}{*}{11} & $0.25 \mathrm{mg}$ & 18 & 0.2 & 1.5 & 7.5 & 650 \\
\hline & & $0.5 \mathrm{mg}$ & 3 & 0.8 & 2.32 & 2.9 & 190 \\
\hline & & $1.5 \mathrm{mg}$ & 31 & 0.41 & 1.84 & 4.48 & 348.7 \\
\hline & & $3 \mathrm{mg}$ & 3 & 1.3 & 1.8 & 1.38 & 38.46 \\
\hline & & $5 \mathrm{mg}$ & 40 & 0.93 & 4.21 & 4.52 & 352.6 \\
\hline & & $10 \mathrm{mg}$ & 32 & 1.6 & 6.24 & 3.9 & 290 \\
\hline & & $20 \mathrm{mg}$ & 8 & 4 & 6.66 & 1.66 & 66.5 \\
\hline & & Inj. $5 \mathrm{mg} / \mathrm{ml}$ & 11 & 4.5 & 8 & 1.77 & 77.77 \\
\hline & & Inj. 50mg/ ml & 2 & 114 & 118 & 1.03 & 3.5 \\
\hline & & Inj. $50 \mathrm{mg} / 10 \mathrm{ml}$ & 5 & 110 & 176 & 1.6 & 60 \\
\hline & & 30ml syrup & 5 & 28 & 59.19 & 2.11 & 11.39 \\
\hline Triflupromazine & 1 & Inj $10 \mathrm{mg} / \mathrm{ml}$ & 2 & 3.5 & 6.03 & 1.72 & 72.28 \\
\hline \multirow{3}{*}{ Trifluoperazine } & \multirow{3}{*}{3} & $1 \mathrm{mg}$ & 3 & 0.36 & 2.36 & 6.55 & 555.5 \\
\hline & & $5 \mathrm{mg}$ & 13 & 0.45 & 2.68 & 5.95 & 495.55 \\
\hline & & $10 \mathrm{mg}$ & 5 & 0.5 & 1.4 & 2.8 & 180 \\
\hline Fluphenazine & 1 & $25 \mathrm{mg} / \mathrm{ml} \mathrm{Amp}$ & 6 & 23.76 & 30.45 & 1.28 & 28.15 \\
\hline Penfluridol & 1 & $20 \mathrm{mg}$ & 4 & 8 & 9.13 & 1.14 & 14.12 \\
\hline \multirow{5}{*}{ Flupenthixol } & \multirow{5}{*}{5} & $0.5 \mathrm{mg}$ & 7 & 1.87 & 3.5 & 1.87 & 87.16 \\
\hline & & $1 \mathrm{mg}$ & 6 & 2.66 & 4.39 & 1.65 & 65.03 \\
\hline & & $3 \mathrm{mg}$ & 4 & 6.71 & 9.45 & 1.4 & 40.83 \\
\hline & & Inj 20mg/ml & 2 & 97.7 & 131.8 & 1.34 & 34.9 \\
\hline & & Inj $40 \mathrm{mg} / 2 \mathrm{ml}$ & 3 & 89.2 & 127.78 & 1.43 & 43.5 \\
\hline \multirow{4}{*}{ Thioridazine } & \multirow{4}{*}{4} & $10 \mathrm{mg}$ & 7 & 0.9 & 1.19 & 1.32 & 32.22 \\
\hline & & $25 \mathrm{mg}$ & 17 & 1.33 & 3.4 & 2.55 & 155.6 \\
\hline & & $50 \mathrm{mg}$ & 14 & 3.05 & 5.2 & 1.70 & 80.32 \\
\hline & & $100 \mathrm{mg}$ & 10 & 5.5 & 8.8 & 1.6 & 69.23 \\
\hline
\end{tabular}

Our study findings showed a high fluctuation in the minimum and maximum price of antipsychotic drugs which are being manufactured by several companies.

The cost of many of the antipsychotic formulations has a percentage price variation above $100 \%$ reaching a maximum of $2282.85 \%$. This is in accordance with similiar studies done for antidiabetic, antiepileptic and antihypertensive drugs. ${ }^{1-4,6,12-14}$

Possible reasons for this could be due to companies offering incentives to the physician for prescribing a particular brand. ${ }^{3}$ Also at times, pharmacist does not dispense the same brand as prescribed by the doctor and substitute it with some other brand, quoting the reason as non-availability. ${ }^{15}$ This is done for the economic gains as some brands have a higher profit margin. ${ }^{15}$ Inadequate government regulation and pricing policies, raw material cost, promotion and distribution cost, existing market structure, asymmetry of information etc. could also be the possible reasons. ${ }^{1-3,13-15}$

In India, most of the patients are paying the medical bills out of their own pockets and are not covered by insurance schemes like developed countries. ${ }^{1,13}$ Hence, there is a urgent need to control the price variation among different brands available in the market. ${ }^{1}$

Hence, the concerned authorities should frame policies for regulating the drug prices. ${ }^{13}$ Also the prescribers should be sensitized regarding the cost of different drugs and a manual of comparative drug prices of different generic and brand drugs should be provided. ${ }^{13}$ 
Table 2: Cost variation among atypical antipsychotic drugs.

\begin{tabular}{|c|c|c|c|c|c|c|c|}
\hline Drug & Formulation & Dose & $\begin{array}{l}\text { Manufacturing } \\
\text { company }\end{array}$ & $\begin{array}{l}\text { Min price } \\
\text { (INR) }\end{array}$ & $\begin{array}{l}\text { Max price } \\
\text { (INR) }\end{array}$ & \begin{tabular}{l|} 
Cost \\
ratio
\end{tabular} & $\begin{array}{l}\% \text { Price } \\
\text { variation }\end{array}$ \\
\hline \multirow{7}{*}{ Olanzapine } & \multirow{7}{*}{7} & $2.5 \mathrm{mg}$ & 61 & 1.1 & 2.5 & 2.27 & 127.27 \\
\hline & & $5 \mathrm{mg}$ & 94 & 1.79 & 5.5 & 3.07 & 207.26 \\
\hline & & $7.5 \mathrm{mg}$ & 43 & 2.8 & 9.67 & 3.45 & 245.35 \\
\hline & & $10 \mathrm{mg}$ & 89 & 2.5 & 11.19 & 4.47 & 347.6 \\
\hline & & $15 \mathrm{mg}$ & 30 & 5.5 & 9.57 & 1.74 & 74 \\
\hline & & $20 \mathrm{mg}$ & 23 & 7 & 12.4 & 1.77 & 77.14 \\
\hline & & Inj 10mg & 2 & 44 & 55 & 1.25 & 25 \\
\hline \multirow{6}{*}{ Risperidone } & \multirow{6}{*}{6} & $0.5 \mathrm{mg}$ & 2 & 1.4 & 1.9 & 1.35 & 35.71 \\
\hline & & $1 \mathrm{mg}$ & 50 & 0.68 & 13.5 & 19.85 & 1885.29 \\
\hline & & $2 \mathrm{mg}$ & 58 & 1.29 & 26.6 & 20.62 & 1968.99 \\
\hline & & $3 \mathrm{mg}$ & 39 & 1.7 & 40.5 & 23.82 & 2282.35 \\
\hline & & $4 \mathrm{mg}$ & 35 & 2.6 & 54 & 20.76 & 1976.92 \\
\hline & & $60 \mathrm{ml}$ suspension & 3 & 97 & 764.1 & 7.87 & 687.73 \\
\hline \multirow{4}{*}{ Clozapine } & \multirow{4}{*}{4} & $25 \mathrm{mg}$ & 20 & 1.3 & 2.85 & 2.19 & 119.23 \\
\hline & & $50 \mathrm{mg}$ & 14 & 2.6 & 4.8 & 1.84 & 84.61 \\
\hline & & $100 \mathrm{mg}$ & 19 & 3.9 & 7.7 & 1.97 & 97.43 \\
\hline & & $200 \mathrm{mg}$ & 3 & 10.59 & 15 & 1.41 & 41.64 \\
\hline \multirow{6}{*}{ Quetiapine } & \multirow{6}{*}{6} & $25 \mathrm{mg}$ & 19 & 1.6 & 3.8 & 2.37 & 137.5 \\
\hline & & $50 \mathrm{mg}$ & 18 & 2.5 & 5.1 & 2.04 & 104 \\
\hline & & $100 \mathrm{mg}$ & 28 & 4 & 11 & 2.75 & 175 \\
\hline & & $200 \mathrm{mg}$ & 25 & 7.8 & 14 & 1.79 & 79.48 \\
\hline & & $300 \mathrm{mg}$ & 13 & 11 & 16.5 & 1.5 & 50 \\
\hline & & $400 \mathrm{mg}$ & 4 & 15.27 & 21.8 & 1.42 & 42.76 \\
\hline \multirow{5}{*}{ Aripiprazole } & \multirow{5}{*}{5} & $5 \mathrm{mg}$ & 8 & 3 & 4.7 & 1.56 & 56.66 \\
\hline & & $10 \mathrm{mg}$ & 29 & 5.2 & 14.4 & 2.76 & 176.9 \\
\hline & & $15 \mathrm{mg}$ & 27 & 7 & 19.5 & 2.78 & 178.57 \\
\hline & & $20 \mathrm{mg}$ & 19 & 9.6 & 23.7 & 2.46 & 146.87 \\
\hline & & $30 \mathrm{mg}$ & 23 & 11.47 & 20.65 & 1.79 & 79.72 \\
\hline \multirow{5}{*}{ Amisulpride } & \multirow{5}{*}{5} & $50 \mathrm{mg}$ & 23 & 4.5 & 7.59 & 1.68 & 68.66 \\
\hline & & $100 \mathrm{mg}$ & 27 & 7.6 & 12 & 1.57 & 57.89 \\
\hline & & $200 \mathrm{mg}$ & 22 & 14.76 & 20.11 & 1.36 & 36.24 \\
\hline & & $300 \mathrm{mg}$ & 6 & 19.85 & 23 & 1.15 & 15.86 \\
\hline & & $400 \mathrm{mg}$ & 4 & 27.2 & 39.29 & 1.44 & 44.44 \\
\hline \multirow{2}{*}{ Pimozide } & \multirow{2}{*}{2} & $2 \mathrm{mg}$ & 10 & 1.15 & 5.1 & 4.43 & 343.47 \\
\hline & & $4 \mathrm{mg}$ & 10 & 1.72 & 7.28 & 4.23 & 323.25 \\
\hline \multirow{4}{*}{ Loxapine } & \multirow{4}{*}{4} & $10 \mathrm{mg}$ tab & 3 & 3.8 & 3.9 & 1.02 & 2.63 \\
\hline & & $25 \mathrm{mg}$ tab & 3 & 7.78 & 8.5 & 1.09 & 9.25 \\
\hline & & 10mg cap & 3 & 3.39 & 4.5 & 1.32 & 32.7 \\
\hline & & $25 \mathrm{mg}$ cap & 3 & 7.06 & 10 & 1.41 & 41.64 \\
\hline
\end{tabular}

Table 3: Percentage price variations and number of formulations.

\begin{tabular}{|ll|}
\hline Percentage price variation & No of formulations \\
\hline$\leq 24.99 \%$ & 6 \\
\hline $25-49.99 \%$ & 14 \\
\hline $50-99.99 \%$ & 19 \\
\hline $100-499.99 \%$ & 26 \\
\hline$\geq 500 \%$ & 7 \\
\hline
\end{tabular}

Also the doctors should be encouraged to write the generic names of the drug and a cheaper brand should be prescribed whenever possible because the superiority of one particular brand over the others has not been scientifically proved. ${ }^{13}$ These steps can help in providing cost effective therapy to the patients thereby improving the compliance.

At present, only a few drugs are under the Drug Price Control Order. ${ }^{12,13}$ For the overall betterment of the 
healthcare of our country, it is desired that government should try and get all the drugs under the DPCO. ${ }^{13}$

Lastly, Pharmacoeconomics should be an integral part of undergraduate and post graduate medical education in order to create awareness about the impact of cost on the treatment of the disease. ${ }^{12}$

\section{CONCLUSION}

This study highlights the enormous price variation among different antipsychotic drugs in the Indian Market. Hence it is recommended that necessary measures be taken to maximize the benefits of therapy and minimize the negative economic and personal consequences.

Funding: No funding sources

Conflict of interest: None declared

Ethical approval: Not required

\section{REFERENCES}

1. Karve AV, Chattar KB. Cost Analysis Study of Oral Antihypertensive agents available in Indian market, IJBCP International Journal of Basic and Clinical Pharmacology. International Journal. 2014 May;3(3):479.

2. Date AP, Mahajan HM, Dashputra AV, Bhosale RR. Study of variation in price of various antidiabetic drugs available in Indian market. International Journal of Basic and Clinical Pharmacology. 2015;4(1):36-40.

3. Hussain S, Pharm M. Cost variation analysis of Oral Hypoglycaemic agents available in Indian market: An Economic Perspective. International Journal of Pharma Sciences and Research. 2015;6(5):913-8.

4. Kamath L, Satish GR. Cost variation analysis of antihypertensive drugs available in Indian market: An economic perspective. International Journal of Pharmaceutical Sciences and Research. 2016 May;7(5):2050.

5. Kulkarni U, Dalvi K, Moghe VV, Deshmukh YA. Pharmacoeconomics: An emerging branch in health sciences for decision making. African Journal of Pharmacy and Pharmacology. 2009 Aug 31;3(8):3627.

6. Atal S, Deshmankar B, Nawaz SA. Cost analysis of commonly used drugs under price control in India:
Assessing the effect of drug price control order on brand price variation. International Journal of Pharmacy and Pharmaceutical Sciences. 2016 Apr;8(4):315-21.

7. Compendium of notified ceiling prices of Schedule Drugs. National Pharmaceutical Pricing Authority 2015. Available from: http://www.nppaindia.nic.in/DPCO2013.pdf

8. Kumar V, Gupta NV, Kumar AK. A Comparison between old and latest systems in DPCO. Int J Pharm Pharm Sci. 2014;6:19-20.

9. Moncrieff J, Cohen D, Mason JP. The subjective experience of taking antipsychotic medication: a content analysis of Internet data. Acta Psychiatrica Scandinavica. 2009 Aug;120(2):102-11.

10. Gardner DM, Baldessarini RJ, Waraich P. Modern antipsychotic drugs: a critical overview. Canadian Medical Association Journal. 2005 Jun;172(13):1703-11.

11. Harichandran DT, Viswanathan MT, Gangadhar R. Adverse drug reactions among hospitalized patients in Psychiatry Department in a Tertiary Care Hospital. Journal of Health Research and Reviews. 2016 May;3(2):77.

12. Shukla AK, Mehani R. Cost analysis of antiepileptic drugs available in India. International Journal of Basic and Clinical Pharmacology. 2016;5(4):163640.

13. Nallani VR. Cost analysis study of oral anti-diabetic drugs available in Indian Govt. Generic (Jan Aushadhi, Jeevandhara) drugs and brand drugs market in rural/urban area of Guntur, Andhrapradesh, India. Value in Health. 2015 Nov;18(7):A717.

14. Shrestha B. Cost analysis of oral antihypertensive agents available in Nepal. Journal of Institute of Medicine. 2015 Nov;38(2).

15. Jadhav NB, Bhosale MS, Adhav CV. Cost analysis study of oral antidiabetic drugs available in Indian market. International Journal of Medical Research and Health Sciences. 2013;1(2):63-9.

Cite this article as: Shah NP, Chincholkar AS, Wagh RJ, Siddiqui WA. To evaluate the creatinine clearance and compare nephrotoxic potential of amikacin and Gentamicin, in post-operative patients with normal baseline renal function. Int $\mathrm{J}$ Basic Clin Pharmacol 2017;6:684-8. 